\title{
THE STATE, POLICIES AND CATTLE RUSTLING
}

\author{
Ali S. Barilla, Kuden Plang I. Sharpspear \& John Isaac \\ Authors are all Post Graduate Student of Political Science Department Ahmadu Bello university Zaria Nigeria. \\ *Correspondence Author: email: barill2015@gmail.com \\ DOI: $10.31364 / \mathrm{SCIRJ} / \mathrm{v} 7 . \mathrm{i3} .2019 . \mathrm{P} 0319627$ \\ http://dx.doi.org/10.31364/SCIRJ/v7.i3.2019.P0319627
}

\begin{abstract}
The paper assesses cattle rustling in relation to social contract, policies and the state. It looks at the causes of cattle rustling and the different policy actions of some states pertaining curtailing the menace. Social contract theory as propounded by Jean Jacque Rousseau was utilized in the explanation of the work. The work expounded that some states are more serious than others in terms of human security most especially in the area of curtailing organised crimes like cattle rustling which in turn earn the state more legitimacy from the citizenry, and it also signifies that those state are operating in line or are making necessary efforts through their policy actions to keep to the terms of the social contract pact made in the state of nature by the state and the citizens. Data used in the paper were sourced using secondary means which form the bases of the method used in the work. Different literature were accessed and assessed and the paper was critiqued, meanwhile the conclusion of the paper posits that the social contract pact should be revisited to serve its original function in the state between the state and the citizens so as to earn legitimacy, policies should be problem solving in their entire inclination when ever they are formulated and implemented in such a way that will guarantee the protection of life and property of the citizenry which will further keep the state existing in line with the terms of the social contract pact hitherto.
\end{abstract}

Keywords: State, Cattle Rustling, Social Contract, Policy

\section{INTRODUCTIONS}

The major functions and responsibilities of every state among other things, is the protection of life (security) and property of the citizenry. This is in exchange with the natural freedom mankind earlier enjoyed in the state of nature as conceived by Rousseau, which is consequential to the terms of social contract mankind engaged himself in with the state (government, community, government, leviathan, sovereign) (Appadorai, 2004; Dunmoye, 2014; Unobe, 2014). This is according to the mechanical conception of the state (mechanical theory of the state). Few states succeeded in keeping to terms of the social contract while many other states failed in keeping to the terms of the social contract, as the result many citizens frequently loss their lives and properties from time immemorial till date.

In the states that are relentlessly working towards keeping the terms of the social contract between mankind and the state, policies and political processes are seriously geared towards protection of lives and properties of the entire citizenry. This is because any policy that in its formulation and implementation challenges the protection of lives and properties of the citizenry is challenging the social contract, hence, detrimental to the existence of the state entirely. Based on the mechanical conception of the state, without the social contract, or if any issue is changing the social contract, it is latently challenging the existence of the state.

Cattle rustling has been a major challenge to the governance, economy, national security and social other of many nations across the globe in time past and in recent time. Cattle rustling as a menace eroding the political and socio-economic balance of many nations 
has been an issue calling at the attention of policy makers across the globe in time past and at present. This lends credence to policies concerning curtailing the menace of cattle rustling. The point of departure in this thesis is the investigation of the policy actions of different states concerning the menace of cattle rustling, this form the problematic of the thesis. Numerous schools came with different perspectives concerning cattle rustling in its causation and prevalence, to some cattle rustling is a resource based conflict (economical), while to others it is a sort of organised crime or terrorist activity(terror brand cattle rustling) in its causation and prevalence. To the two schools these are the drives, motives, rationale or perspectives of cattle rustling on a general note.

\section{CONCEPTUAL CLARIFICATION}

Metaphorically, Conceptual clarification in a thesis is like unto house cleaning. It gives a thesis good shape and clear direction for better and ease comprehension even to a lay man Unobe (2013).

State: state could be define as a sovereign population or group of people with a definite territory and government Appadorai (2004).

Cattle Rustling: cattle rustling is an act of abetting or stealing grazing cattle there are distinctions between cattle raid and cattle rustling based on the number of the cattle stolen and organization or mode of carrying out the act cattle rustling. Cattle raid is traditional and carried out using traditional weapons like bows, arrows, spear, stone, and the number of the stolen cattle are less than fifty (50)while cattle rustling is carried out using modern sophisticated weapons like Ak47 with stolen cattle ranging from fifty (50) to 300 hundred and above.

Social Contract: The social contract stipulates that: in the state of nature there was no government, there was no law which could be enforced by a coercive authority. Men lived, it was said, it was aid in a state of nature, in which they were subject only to such regulations as nature was supposed to prescribe. But there was no human authority to formulate and prescribe precisely the rules and how to enforce them. After some time, men decided to set up a government. Thereby, they parted with their natural liberty and agreed to obey the laws prescribed by the government Appadorai (2004).

Policy: Policies are government's decisions, principles and guide action and inaction concerning political, economical and social spheres of life within a territory.

\section{THEORY}

The work utilizes social contract theory as propounded by Jean Jacques Rousseau (1762). Rousseau was born (1712- 1778), his thesis contract social was developed in (1762) the thesis is one of the factors that inspired the French revolution of 1789 which was a revolt against the French despotic monarchy, it also form the bases of popular sovereignty. The cohorts of Rousseau includes: Thomas 
Hobbes and John Locke among others (the mechanical theorists of the state). According to Rousseau man is essentially good and sympathetic as found in the state of nature, he forwarded that in the state of nature men were free and equal, there was idyllic happiness, but with the introduction of private property, material acquisition and the increase in number, quarrels arise and man is compelled to give up his natural freedom and rights, to find a form of association which protect with the whole common force the person and his property. Every man who is an associate become as free as before, the problem of men is solve through the contract and the creation of the civil society.

In the contract every man surrenders to the community all his rights, the community becomes sovereign. The sovereignty is exercise in the interests of the subjects, because the sovereign body being formed only of the individuals who constitute it. The sovereign body has no interest which contradicts the interest of the subjects.

\section{WEEKNESS OF THE THEORY}

Theory is utopia, on the bases that the state has no interest that contradicts that of the subjects. It is not possible for the state to have the same interests with the subjects at all time. Secondly individual in the state differs from one another in their interests at individual, group and community level, with different numerous and contradicting priorities based on the nature of the community and the social order. This again, makes it difficult for the state to fit into the interests of these different categories at all times in the exercise of its functions, most especially in the area of human security which is the part of the thrust of the discuss.

\section{STRENGHT OF THE THEORY}

The theory brings to fore the reason for the existence of the state and the functions the state is meant to execute in the society and in the lives of its subject if it must exist and be legitimate among other things. The theory, also enlighten the subjects to know that the state is surmountable when ever it failed to execute functions which it is form to do.

\section{APPLICATION OF THE THEORY TO WORK}

The sate as it is saddle with the functions of human security which includes the protection of the life and property of subjects. The state or the government is the chief custodian of human security, it ensure that human security is given the required priority and attention both in theory and actions of the government. By implication the protection of the lives of herdsmen and cattle is the responsibility of the government based on the prescriptions of social contract as postulated by Rousseau. This means that the state is to coordinate the activities of cattle breeders in their interest which will indicate that the state has fulfilled its portion of the pact appropriately. It is also the responsibility of the state to handle the activities of culprits of cattle rustling to preserve the life and 
property of cattle breeder of which the state will be rewarded with legitimacy and recognition (compliance) from the cattle breeders and other subjects that are vulnerable to the harms of cattle rustling.

\section{LITERATURE}

Within the confine of social contract theory the state and government are interchangeably used to mean the same thing. The state in the ideal sense has the following functions to carry out, these functions also calls for the existence of the state. They are:

\section{Law Making}

2. Protection of lives and property of the citizens(human security)

3. Defence of the state(country)

4. Maintenance of law and order

5. Justice administration

6. Provision of social services

7. Provision of employment opportunities

8. Economic functions

9. Political functions

10. Maintenance of external relations

Based on the trends and dynamics of the menace of cattle rustling it is critically observed that in the states the menace persisted, the state inadequately dispense its functions as listed. when the state properly carry out its functions, it will manifest on the policies, hence organised crimes like cattle rustling will be rightly tackled which will brings about legitimacy and strengthen the need for the existence and efficiency of the state as expected from the social contract.

\section{Causes of cattle rustling}

There are numerous causes of cattle rustling different from one another depending on the environment that informed the act and nature of victimizing area. These causes include:

\section{General Causes of Cattle Rustling}

In the Eastern region of Africa most especially in Kenya, cattle rustling is the dominant cause of conflicts among the Pokot, Masaai, Marakwet and other pastoral community members. Cattle rustling in West Pokot County involves the Turkana, Sabaot, Samburu, Marakwet, Sabiny and Karamajong communities and it is a way of life for the pastoralists where pastoral communities like the 'Morans' organized raids and execute as a symbol of dominance. These raids are normally planned, guided and moderated by 
community elders. Usually retaliatory attacks always take place by the rival community elders' at the most appropriate time, although fatality do not occur. However, contemporary raids have become more frequent and fatal. This is attributed to the increase in extreme climatic events, particularly droughts and Proliferation of arms respectively (Huho, 2012).

Most importantly, scholars associate cattle rustling to culture, illegal proliferation of arms, hunger, climate change, boundary disputes, insecurity, political issues, unemployment and economic gain and means of livelihood among others (Greiner, 2013; Okoli and Francis, 2014).

Greiner (2013) although similar to Huho (2012) in his analysis of cattle rustling in Kenya, notices that, livestock raiding among Northern Kenyan pastoralists has profoundly changed from what it used to be. It has been politicized in relation to claims over administrative boundaries, struggles for exclusive access to land, and attempts to establish or safeguard an ethnically homogeneous electoral base. These conflicts are part of Kenya's troubled politics of decentralization and as such, they must be viewed in the context of wider political developments in the country. Based on ethnographic field work in East Pokot and surrounding areas in Kenya's Central Rift Valley Province, this also shows how cattle rustling has become a specific form of violent determining factor and as an adapted, dangerous, and powerful political weapon. He goes on to say that, in studying the patterns of cattle rustling in Kenya the links between raiders and politicians often remain obscure, but the violence in pastoralist areas is intimately linked to recent political developments in Kenya at large. Processes of democratization particularly the re-establishment of multi-partyism in 1992, the end of the Moi regime in 2002, the post-election violence of 2007-2008, the current political administrative restructuring, as well as the ongoing land reforms have created windows of opportunity for violent negotiation of territorial claims in the pastoralist areas in Kenya's arid North. These cause and triggers cattle rustling in Kenya.

Okoli and Francis (2014) also observe that cattle rustling is connected to political struggles as evident in some parts of Africa. They illustrate that, in 2013, many people were killed and wounded in series of massive cattle raids perpetrated, by rebels in Jonglei region of South Sudan. To them the killing and massive cattle rustling took a political perspective. Similarly, in Nigeria, as recoded by Okoli and Atelhe (2014), the spate of cattle rustling in the Northern part of the country in the recent years has sometimes been associated with the activities of the Boko Haram insurgence group. Based on this analysis, it could be said that the views of Greiner (2013), Okoli and Francis (2014) and Okoli and Atelhe (2014) are similar in the way they analyzed the causes of cattle rustling in relations to politics and political processes.

In the case of Plateau State, cattle rustling around 2006 took an ethno-religious form of conflict before it recently metamorphosed into non religious and non ethnic form of crime and violence with its culprits from diverse sects or groups in the state (Human rights watch report, 2004). As seen by Kwaja (2014) Forms of violence that are linked to cattle rustling underpinned by criminality now 
pervade the central Nigerian area. The rustling of cattle for economic gains represents the primary drive for the attack of defenceless communities. This is part of an economically based form of criminality perpetrated by criminal networks that are illegal and informal in their operations. The rise of an underground economy that is linked to cattle rustling is increasingly being fuelled by a climate of insecurity and violence, which also underpins ethno-religious and communal conflicts in the central Nigerian area as a result of political and structural imbalance.

It is noted that in the recent years, the central area of Nigeria has become a major flash point of all sorts of violence and conflicts, with a lot of criminal activities and rural arm banditry challenging the area. It is also observed that in North central region of Nigeria, cattle rustling is one of the major issue impacting on livelihood based on the linkage of livelihood opportunities and the devastating impact of cattle rustling in relations to means of livelihood struggle between farmers and herdsmen, which forms the integral part of Nigeria's political economy from agricultural point of view. The bone of contention lies in the fact that the same land farmers focus on for the production of food and as a means of livelihood is needed by pastoralist for grazing cattle. This is also a means of survival to them. Therefore the struggle over access and control of land between the pastoralist and the crop farmers constitutes the basis for violence and conflict between the two groups. This has led to devastating impact such as cattle rustling, loss of lives, displacements of both the pastoralists and the crop farmers, and destruction of property, in places such as Plateau, Benue, Nasarawa, Niger, and Taraba states. This dynamic trends account for spiral conflict, proliferation of illegal arms coupled with slim opportunities of livelihood in the North central region, all put together candled cattle rustling within the region (Human rights watch report; 2004 and Kwaja, 2014).

Based on the study, there are numerous causes of cattle rustling. These causes could be classified into four broad categories. They are cultural causes, ecological causes, economic causes, and political and colonial antecedent.

Cultural causes of cattle rustling: According to Ngaga, (2012), the cultural practice of giving dowry before marriage is a major cause of cattle rustling. It is evident that this factor has had a major impact on the spread and practice of the culture of cattle rustling and conflict in the North rift part of Kenya. This cultural practice has made the Pokots, the Marakwet and the Masaai among others think that cattle rustling is a normal way of life.

It is also noted among the Pokots in Kenya that there exist the practice of 'Sapana' (a Pokot male traditional rite of passage from adolescence to elder hood) which influences cattle rustling. During 'sapana' ceremony, the man spears his favourite bull and serves meat to his friends and other elders, after which he is officially introduced to the elder hood club and is allowed to participate in community matters as an elder. Those who have not served 'sapana' meal have no say in community matters. The 'sapana' cultural rite encourage the young adults to acquire bulls by whatever means so that they could be respected in the community. Women are identified as one of the major factors that triggered the spread of cattle raid because they celebrate successful cattle raiders with songs 
while using mockery against those who did not participate in raids. The women respect men with huge herds of cattle, while those without cattle are seen as cowards and not respected. The women always had songs for each occasion when raids are conducted successfully (Cheserek, Omondi and Odenyo, 2012). Similarly, cattle rustling in North America, is also seen as culture among the Texan cowboys (Baker, 1945 and Derricourt, 1899).

In the same vein, Manu, Andu, Tarla and Agarih (2014) observe that, traditionally, cattle rustling among the pastoral communities in other parts of the world are considered as a cultural practice which is sanctioned and controlled by the elders. This shows that in East Africa, most especially among the herders in Kenya, Uganda and Lesotho cultural rites and practices are the major causes of cattle rustling. Manu et al (2014) further posit that it is from the cultural practice over a period of time that the cultural raid developed new trends, tendencies and dynamics, leading to commercialization and internationalization of the practice, contrary to the views of early scholars who trivialize cattle rustling as a mere cultural practice. By way of inference, it could be deduced that the cause of cattle rustling among the Pokot and the Marakwet people of Kenya is largely attributed to cultural practices, traditions, customs, values and beliefs (Manu et al, 2014; Cheserek et al; 2012, Ngaga, 2012). Although there are other factors that cause cattle rustling among the Pokot and the Marakwet people the major cause identified by the scholars is the culture and tradition of the Pokots and the Marakwet.

Contrary to the view of Manu, et al 2014, Cheserek, et al, 2012, Ngaga, 2012 who view tradition and culture as the cause of cattle rustling, other scholars associate the cause of cattle rustling to politics, institutional setups and colonial antecedence. According to McCabe (2004), tribal-based politics is one of the major causes of cattle rustling in Kenya, while Adano, W. Dietz, T. Witsenburg, K and Zaal, F. (2012) observes that faulty institutional set-ups is one of the factors causing cattle rustling in Kenya. Kwaja (2014) in another way closer to the argument of Adano et al., (2012) and McCabe (2004) notes that in Plateau State, one important source of tension between ethno-religious groups is the question of 'indigenousness', which means that some groups have access to political power, resources, employment and education in state or local government areas (LGAs), while migrants from other areas are relatively excluded. It is glaring that this is a constitutional issue that needs to be properly addressed. It is also observed that these imbalance institutional arrangements are directly and indirectly regarded as some of the issues that exacerbate cattle rustling in Plateau State as it is in Kenya.

Furthermore, the proliferation of arms has fed growing criminality, contributed to an upsurge in cattle rustling and increased the longstanding tensions between pastoralists and agriculturalists in Plateau State. This demonstrates how unbalance structural arrangement, politics of ethnicity and religion as a corollary cause cattle rustling in Plateau State, again it is noted that marginalization is the result of distributive injustice in a nation. According to McCabe (2004), it is visible that the government of Kenya uses its resources in already developed areas and fails to balance the same developments in the Pokot districts which need preferential 
consideration in budgetary allocation. This has resulted in poverty, despair and increase crime which accentuate the culture of cattle rustling. Consequently, the Pokot community remains stuck in their traditional culture without socializing with other wider cultures. This also shows how unbalance structural arrangement among policy makers in Kenya influence cattle rustling among the Pokots, which is also the same with the case of Nigeria, most especially the case of Plateau State, where policy makers and policies most times do not pay considerable developmental attention to the pastoralists in terms of land tenure and this fuels conflicts resulting to cattle rustling (Kwaja, 2014; Ngaga, 2012).

It is also observed that most institutions within systems are not properly functioning in the ideal way they supposed to. The law enforcement agencies charged with the duty of maintaining law, order and security within the state are always inadequate in the discharge of their function which leads to spiral violence, injustice, mistrust of security personnel, proliferation of arms and in efficient service put together politically and structurally causes cattle rustling and other related violence. This indicates how the state structurally fuels and causes cattle rustling either directly or indirectly (Kwaja, 2014; Kaprom, 2013). Greiner, (2013), notes that while the political dimensions of inter-tribal violence are largely explicable, the nexus between political leaders and the actual raiders is much less clear. Greiner (2013) further observes that it is evidence that Kalenjin politicians in Kenya are actively involved in the distribution of modern firearms to the Pokot in the mid-1990s. He further notes that in 1982 in some cases, such as in the rustling attacks against the IlChamus, the actions of the raiders were openly instigated by politicians.

It is evident that the pastoralist communities in Kenya and Uganda experience years of successive marginalization both politically and economically during the period of colonization to the present independence. This may be attributed to the fact that at the advent of colonialism, many pastoralist communities were unwilling to adopt new cultures and changes that the white man brought, and consequently, they were relegated and forced to relocate to the unproductive regions of the pastoral communities, due to their deep culture and their nomadic way of living, failed to obtain the white man's education. Lack of western education among the pastoralist communities partly explains their failure to actively participate in the political governance of the country at independence and after. For many years, the pastoral communities have been sidelined by the Government from the mainstream of the countries socioeconomic and political fronts. Pastoralist areas are the least developed and the infrastructure is poorly developed. There are few schools, health facilities and poor telecommunication services.

Indeed, the disparity in the economic and living standards between most of the pastoralists and the rest of the country is extremely wide. It is further noticed that the extent of the marginalization has been clearly illustrated in a document prepared by the Ministry of State for the Development of Northern Kenya. Another marginalization of the pastoralist communities is further exacerbated by the 
"war-like" tag which had been placed on these communities by the colonialists (Kenya Human Rights Commission, 2010). This is seen as one of the causes of cattle rustling within the region.

It could be reasoned that political instrumentalisation and marginalization, and also the demarcation of political administrative boundaries between the Pokot and Turkana grazing range is considered a contributing factor to cattle rustling. This argument is in tandem with the position of Ngaga (2012) about the political causes of cattle rustling in Kenya, but with little distinction because the (Kenya Human Rights Commission, 2001) document advances and traces the political causes of cattle rustling in Kenya from colonial ill political arrangements.

Chepwarwa (2003) opine that the pre-colonial favourable arrangements among the Kenyan herders is however, destabilized by colonial authorities. The impact of colonial policy on relations between the Turkana and Pokot is to accentuate underlying hostilities and to encourage greater competition for resources shared in environments lying on or near to the administrative boundaries. This arrangement causes cattle rustling among the Masaai and latter the other pastoral tribes of Kenya.

Cheserek, et al (2012) also noted that Poor leadership has also contributed to the issue of cattle rustling in Kenya. The same poor leadership is one of the major causes of cattle rustling in Nigeria most especially in Northern Nigeria with reference to Plateau State, this is confirmed by Kwaja (2014). In his word when he viewed the state and its policies and structural arrangements as one of the major causes of cattle rustling in Plateau State where the area of study is located.

Although cattle rustling among the East African pastoral ethnic groups is seen as a cultural practice, there is also an economic intent in their cultural practice of cattle raid. In laying claims, to economic factor as one of the major causes of cattle rustling, it is observed that over time, the cultural practice of cattle rustling has transformed and emerge with new trends, tendencies and dynamics, leading to commercialization and internationalization of the practice contrary to the views of early scholars who conceived cattle rustling as a mere cultural practice (Manu, et al,.2014). Cattle rustling is no longer driven by culture and tradition in its intent and motive, rather, the commercial benefits among other things are the driving force of cattle rustlers.

To further buttress the fact that the economic benefits are the motivating factors of cattle rustling Schilling, J., Opiyo, E and Jurgen, S. (2012) and Dzimba and Matooane (2005) observe that in Cameroon, cattle rustling is not a cultural practice and tradition in the country's North West Region compare to the situation in the Horn of Africa (Kenya, Uganda, Lesotho, and Somalia). In these areas, there is rampant inter-tribal or inter community conflicts, therefore, cattle rustling in the North West Region of Cameroon is practiced purely as a commercial activity and for individual gains. It is point out that those cattle rustling are not only committed by unemployed or poor individuals but also by well organized groups that have buoyant financial and asset backing. These groups are often wealthy enough to move animals by means of trucks and trailers. Cattle rustling is also encouraged by the ease with which 
stolen animals can be traded (Dzimba, et al, 2005, Manu et al, 2014) therefore, stolen stock is sold without the necessary documentation to individuals for immediate use in communal celebrations and funerals and also to butchers at very low prices.

Kwaja (2014) supports the above when he says that the commercialization of cattle rustling is largely due to the existence of a viable market that bridges the chasm between demand and supply. He further claims that in Northern Nigeria, cattle rustling and culprits engage in the act because of the economic gain and marketable value of cattle. This corroborates the claim of Schilling (2012), and Dzimba and Matooane (2005) that in the North West region of Cameroon cattle rustling is driven by the economic gains unlike in the horn of Africa where the act of cattle rustling is acclaimed to culture and tradition before 1990s.

Krätli and Swift (2003), and Buchanan-Smith and Lind (2005) in their studies about the causes of cattle rustling observe that there are many causes and motives for cattle rustling but the major cause is the commercialization of the act. According to them the commercial value of cattle triggers the act of cattle rustling. This also supports the fact that people who engaged in cattle rustling are not only unemployed or poor, but are driven by the commercial benefits attached to it as reported by Schilling et al (2012), and Dzimba et al (2005). In this case, cattle rustling could be seen as an illegal commercial venture just like drug dealing, human trafficking, and prostitution in some parts of the globe.

In this regard, it is important to observe that the phenomenon of cattle rustling in Nigeria has been driven by criminal quest for economic accumulation in an environment that more or less condones crimes. The commercial intent and gains of cattle rustling makes and qualifies cattle rustling as a typical example of an organized crime like drug cartel and syndicates which are global challenges that requires global effort to be combated.

Cheserek, Omondi and Odenyo (2012) observed that:

There exist already made illegal market arrangements among the Pokot and Marakwet communities accounting for $23 \%$. Commercialization of rustled cattle, commercialization here refers to the ready market or cash for rustled cattle. Unscrupulous business people with good links to politicians and senior government officials were reported to have organized and supervised cattle rustling for individual gain and influence. They purchase stolen livestock at low prices and fetching high profits by selling them in major urban centres and international markets. These activities implied raiding had become a source of livelihood to those who owned guns and a means of making quick wealth for the politically connected.

The citation portrays cattle rustling as an organized illegal economic venture in its intent and marketing in the horn of Africa. This is not only typical of the Pokot and Marakwet but also the same with the case of North West Cameroon and Northern Nigeria. The same 
is found in the ancient Europe (Derricourt, 1899). This ascertains the fact that all over the globe the major cause and motive for cattle rustling is the economic gains and the commercial value of cattle.

In another dimension although in line with the causes of cattle rustling, it is also observed that environmental and ecological factors are some of the causes of cattle rustling apart from the cultural, political and economic discussed above. In this regard, it is noted that climate and issues of environmental change in most cases do lead to competition and scarcity of resources in the form of water, pasture, land resources and livestock assets, as a result, it generates into conflicts between pastoral groups and crop farming groups. This implies that the cattle rustling violence (conflict) most especially in the Eastern Africa is partly due to environmental and ecological imbalances. It is evident that cattle rustlers engage in rustling for different reasons (Mkutu 2006; Gray et al., 2003, Adano et al. 2012, Campbell et al., 2009; Schilling et al., 2012; Witsenburg and Adano et al., 2009; Meier et al., 2007).

It is also revealed among the Somali people that cattle rustling is conducted during dry season to recover livestock lost during the rainy season. Similar to the case of Somali, is that cattle rustling most times among the pastoralists in West Pokot County largely revolves around competition over control and access to pasture and water resources emanating from extreme climatic events. Conflicts were common in lowlands areas due to shortage of water and pasture, food insecurity and high poverty levels caused by prolonged dry periods. The wet highlands provided sustainable livelihood source and therefore were more peaceful. Based on these cases, it could be generally deduced that cattle rustling in some areas is compounded by a tendency that pastoral rangelands are both uninhabited and under productive due to whether. This fact strongly supports the notion that some of the motives for cattle rustling are drought and climatic change (Nunow 2000; Schilling and Remling 2011; Huho, 2014).

Contrary to the environmental and the ecological factors which are seen as causes of cattle rustling the causes of cattle rustling in Plateau State are attributed to unemployment, poverty, poor leadership, structural arrangements, religious and ethnic conflict among others Kwaja (2014). This lend credence to the fact that the causes of cattle rustling differ from place to place, group to group and from individual to individual.

Okoli and Francis (2014) identify some general causes of cattle rustling. Based on their claims the prevalence of cattle rustling in Africa today has been associated with a number of predisposing and causative factors, among which are:

I. The worsening material livelihood conditions of the herders arising from the repercussions of climate change and the attendant resource conflicts, tends to be compelling criminal tendencies (cattle rustling) among herders.

ii. Proliferation of arms and ammunition in Africa has placed enormous weaponry in the arms of criminal elements, some of whom perpetrate cattle rustling. In line with this view, Kwaja (2014) also shows that in Nigeria, the proliferation of small arms has fed 
growing criminality, contributed to an upsurge in cattle rustling and increased the longstanding tensions between pastoralists and agriculturalists in the state.

iii. Terrorism and armed rebellion in the sub-Saharan Africa have promoted cattle rustling as a franchise dedicated to funding of group struggles. In line with this, the work of Okoli and Atelhe, 2014; Okoli and Iortyer, 2014) recently shows that the developments in terrorist activities tend to have implicated cattle rustling in the rising wave of violence in Northern Nigeria, as exemplified in the phenomenon of Boko Haram insurgency and herder-farmer conflicts.

iv. The remoteness of grazing fields makes effective surveillance and policing of cattle problematic.

v. The itinerant pattern of grazing in Africa predisposes cattle rustling.

vi. Absence of effective legal framework for mandatory cattle identification and registration has obstructed the fight against cattle rustling.

vii. The porous nature of inter-state border-lines in Africa makes trans-border cattle rustling conducive and thriving.

viii. The criminal impunity of the people, arising from the apparent lethargy of the government to deter crime through drastic penalty.

One major problem with the claims of Okoli and Francis (2014) about the causes of cattle rustling is that the economic or the commercial intent as a cause of cattle rustling is not well captured in their analysis. This tends to be a deficiency because the economic intent has been the major cause of cattle rustling as shown by scholars such as (Manu, Andu, Tarla and Agharih, 2014) among others.

\section{STATES AND CATTLE RUSTLING}

The American state took serious policy action towards curtailing cattle rustling despite the fact that cattle rustling was one of the reagents that fuelled the second world war. The formulation of the mccarant act and its effectiveness indicates that the American state keep to terms of the social contract as in the case of cattle rustling. The act stipulated a huge fine on culprits and it led to the recovering of many stolen livestock. Similar thing happen in Scotland, after the rustling of about 300 cattle the state declared the issue of cattle rustling as an issue of national emergency. This also shows that the government of Scotland keep to the terms of the social contract in the way it responded to the issue of cattle rustling within the state. The same is not the case in many African states, it is so much alleged that in African states the act of cattle rustling and many other organised crimes are politically connected in their causation and persistence. States (governments) are always lacklustre in their policies and entire actions towards curtailing cattle rustling and other organise crimes. 
It is observed in an interview that many casualties and victims of cattle rustling responded that there is a connivance that exist between the culprits of cattle rustling and the state and politicians. This might not be true, but because the state has failed in curtailing the menace such impression was created in the mind of victims. when ever the state failed to safeguard and guarantee human security of its citizenry at any point in time, citizens tends to think that it is intensional, hence legitimacy of citizens to the state weaken, and the social contract tempered with which question the existence of the state in question (Kuden, 2017).

\section{CRITIQUE}

Looking at the state and the individuals the state cannot be able to meet up with the desires and wants of the individuals in any society because the needs and desires of mankind are always contradicting. What a particular person needs or desire is different from what another man needs, same is applicable to communities and societies. To an extent this contradiction is a hindrance to the realization of the social contract. This makes it difficult to apportion blame, whether it is the state or the individual that makes the contract difficult to be fulfil. This is near the debate: the egg and the chicken- which one came first. Some measures taken by the state to curtail cattle rustling will cause havoc to the social order in the society, on the other side, the nature or the social order of some communities does not harbour the measures the state is taking to curtail cattle rustling. The act of cattle rustling and its changing nature in its causes and prevalence tends to differ from community to community and the conception also tends to differ from individuals to individual, some sees it as religious, others ethnical, to some it is economical while some social, all these are complex contradictions that makes it difficult to the state to meet up with its terms of contract in the area of cattle rustling. Although, according to Rousseau in the social contract the sovereign body has no interest that contradicts the interests of the subjects, but it seems utopia.

\section{CONCLUSIONS}

It is pertinent that Human security should be given the priority it deserves. This is because rampant poverty and unemployment have often been unduly politicized and ethicized by self-interested citizens which are major causes of cattle rustling, conflicts and many organize crimes. The State in its policies and policy actions should develop a holistic and realistic socio-political and economic pact with the citizenry. With the exception of few states, social contract is currently in tatters, most especially in Africa the social contract should be re-negotiated through good, transparent and accountable governance to address poverty, promote political inclusiveness, give full expression to social citizenship and put an end to the divisive political economy of ethnicity, bad leadership and crippled problem solving policies and policy actions, so that the state will exist in line with the terms of the social contract pact hitherto.

\section{REFERENCES}

Appadorai, A. (2004). The Substance of Politics. Oxford University Press, New Delhi. (4 ${ }^{\text {th }}$ ed). 
Buchanan-Smith, M and Lind, J. (2005). Armed violence and poverty in Northern Kenya: a case study for the Armed Violence and Poverty Initiative. Bradford: Centre for International Cooperation and Security/Bradford University.

Campbell, I. Dalrymple, S., Rob, C and Crawford, A. (2009). Climate change and conflict- lessons from community conservancies in northern Kenya. Winnipeg: International Institute for Sustainable Development.

Cheserek, G.J., Omondi, A and Odenyo,V. (2012). Nature and Causes of Cattle Rustling among Some Pastoral Communities in Kenya. Department of Applied Environmental Social Sciences, Chepkoilel University College, Eldoret, Kenya.

Chepwarwa, C. (2003). Effects of Cattle Rustling in Education Management in Baringo District .

Derricourt, W. (1899) Old Convict Days (2nd ed.) T.F. Unwin, London.

Dzimba, J and Matooane, M. (2005). Stock Theft and Human Security: A Case Study of Lesotho. Available at:http://www.iss.co.za/pubs/Monographs/No113/Acknow.htm. $\quad$ Accessed January,2013.

Gray, S., Sunal, M., Wiebusch, B, Little, M. A., Leslie, P. W. and Pike, I. L. (2003). Cattle raiding, Cultural survival, and adaptability of East African pastoralists. Current $\quad$ Anthropology, 44 ( $\quad$ (55), 3-30.

Greiner, C. (2013). Guns, Land, and Votes: Cattle Rustling and the Politics of Boundary (re)Making in Northern kenya. African Affairs, 112/447, 216-237 doi: $\quad$ 10.1093/afraf/adt003@ The $\quad$ Author 2013. Published by Oxford University Press on behalf of Royal African Society. All rights reserved Advance Access Publication $3 \quad$ February 2013.

Huho, J. (2012). Conflict Resolution Among Pastoral Communities in West Pokot County, Kenya: A missing link. Department of Geography, Bondo University College, Kenya. 3(3).

Human Rights Watch Report"Jos city turn apart” December (2004).

Kaprom, T. (2013). Effects of Cattle Rustling on Economic Development : A case of Masol location, West Pokot county. Kenya.

Kenya Human Rights Commission (K.H.R.C.) (2001). Raiding Democracy: The Slaughter of the Marakwet in the Kerio Valley. Nairobi.

Krätli, S and Swift, J. (2003). Understanding and managing pastoral conflict in Kenya. Sussex: University of Sussex.

Kwaja, C. (2014). Policy Brief Review Responses to the Plateau State Government to Violence Conflicts in the State.

Kwaja, C. (2014). Blood, Cattle, and Cash: Cattle Rustling and Nigeria's Bourgeoning Underground Economy Background and Context. 
Kuden, P. (2017) Cattle rustling and Socio-Economic Development of Mangu Local

(2010-2016).

Manu, I., Andu, W., Tarla, D and Agharih, W. (2014). Causes of cattle theft in the North West Region of Cameroon. Department of Rural Sociology and Agricultural Extension, Faculty of Agronomy and Agricultural Sciences (FASA), University of Dschang, $\quad$ Cameroon. 4(4).

McCabe, J. (2004). Cattle Bring us Our Enemies:Turkana Ecology, Politics and Raiding in a Disequilibrium System. Ann Abor University of Michigan Press.

McCarran act, 194, and 1994.

Meier, P., Bond, D and Bond, J. (2007). Environmental Influences on Pastoral Conflict in the Horn of Africa. Political Geography 26(6): 716-735.

Mkutu, K. (2006). Small Arms and Light Weapons Among Pastoralist Groups in the KenyaUganda Boarder Area. African Affairs 106 (422): 47-70-Eastern Kenya., University of Amsterdam.

Ngaga, D. (2012). Culture as the Cause of Conflict: A Case study in west Pokot District, Kenya.6 (1).

Okoli, A and Francis, M. (2014). Cattle rustling and the dialetics of security in Nothern Nigeria. Department of Political Science, Federal University Lafia, Nasarawa State, Nigeria (2)3.

Schilling, J and Remling, E. (2011). Local Adaptation and National Climate Change Policy in Kenya: Discrepancies, options, and the way forward. Munich: Paper presented at the Summer Academy on Social Vulnerability: Climate Change and Fragile States: Rethinking Adaptation.

Schilling, J., Opiyo, E and Jurgen, S. (2012). Raiding Pastoral Livelihoods: Motives and effects of violent conflict in northwestern Kenya. Pastoralism: Research, Policy and Practice.

Unobe, E. (2013). Msc lecture note, political science, Amadu Bello University Zaria 